\title{
INTERACTION OF CHALCONES WITH CT-DNA BY SPECTROPHOTOMETRIC ANALYSIS AND THEORETICALSIMULATIONS
}

\author{
Ximena Zarate ${ }^{\mathrm{b}}$, Eduardo Schott ${ }^{\mathrm{c}}$, Carlos A. Escobar ${ }^{\mathrm{d}}$, Roberto Lopez-Castro ${ }^{\mathrm{e}}$, Cesar Echeverria ${ }^{\mathrm{a}, \mathrm{g}}$, Leonor Alvarado-Soto ${ }^{\mathrm{a}, \mathrm{f}}$ \\ and Rodrigo Ramirez-Tagle ${ }^{\mathrm{a}, *}$ \\ aUniversidad Bernardo O’Higgins, Facultad de Ingenieria, Avenida Viel 1497, Santiago, Chile. \\ 'Instituto de Ciencias Químicas Aplicadas, Facultad de Ingeniería, Universidad Autónoma de Chile, Av. Pedro de Valdivia 641, \\ Santiago, Chile \\ 'Departamento de Química Inorgánica, Facultad de Química, Pontificia Universidad Católica de Chile. Avda. Vicuña Mackenna \\ 4860, Santiago, Chile \\ dUniversidad Andres Bello, Departamento de Ciencias Químicas, Republica 275, Santiago, Chile \\ 'Universidad Bernardo O’Higgins, Facultad de Salud, Deporte y Recreación, Escuela de Kinesiología, General Gana 1780, \\ Santiago, Chile \\ ${ }^{f}$ Universidad Finis Terrae, Santiago, Chile \\ 'Universidad Bernardo O’Higgins, Laboratorio de Bionanotecnologia, General Gana 1780, Santiago, Chile
}

Recebido em 11/12/2015; aceito em 27/04/2016; publicado na web em 08/07/2016

\begin{abstract}
Chalcones are open chain molecules precursors of flavonoids and isoflavonoids, found spread in edible plants. Because they are easily accessible trough Claisen Shmidt condensation, a great variety of derivatives are available. They have also shown potential in pharmacological and biological applications. It is known that chalcone derivatives display a role in the treatment of complex diseases such as cancer, among others, where the DNA is considered as the target for the action of these kinds of compounds. This action is commonly explained as the inhibition of the DNA replications and transcriptions through interactions. However, not conclusive associations between these DNA-Drug interactions and toxicity have been found. This research focuses on the capacity of a chalcone`s family to interact with DNA. Therefore, the binding constants for each compounds with Calf Thymus DNA [CT-DNA] were determined by spectrophotometric titration at room temperature. In addition, the effect of increasing the chalcone`s concentration over the relative viscosity of CT-DNA at room temperature was assessed. On the other hand, with the aim to find the optimal DNAchalcone configurations, as well as consistently predict their binding, a computational work was undertaken. To accomplish these goals within a reasonable time framework, an empirical scoring function (AScore) and a docking engine (ShapeDock) were performed using the ArgusLab package. The results of viscosity and docking measurement provided structural insights which suggest that chalcones bind with DNA via interaction as well as intercalation. The presence of interactions is also evidenced by the spectrophotometric study which showed luminescence quenching of the chalcones upon interaction with CT-DNA.
\end{abstract}

Keywords: chalcones; DNA; docking; antitumoral; spectrophotometric analysis.

\section{INTRODUCTION}

Chalcones are open chain molecular systems precursors of flavonoids ${ }^{1}$ and isoflavonoids, present frequently in edible plants.

Structural modification of chalcones has allowed to obtain derivatives which display potential and worthy applications in pharmacological and biological areas like new medicinal agents with improved properties, such as higher potency and lesser toxicity. ${ }^{2}$

This wide range of biological activities associated with many chalcone derivatives, has stimulated interest in the development of synthetic strategies aimed to the synthesis of heterocyclic systems starting from chalcones. Besides of the implementation of efficient methodologies for their obtaining, researches have focused also on the study of their reactivity and the assessment of their possible biological activities. ${ }^{3-5}$

Particularly in the pharmaceutical field, chalcone derivatives have found application on the treatment of different important diseases such as cancer, among others. ${ }^{6-10}$

DNA is thought to be the main target of antitumoral drugs, and the binding between cisplatin complexes and DNA targets have been extensively studied. ${ }^{11,12}$ Authors have shown that DNA interactions

*e-mail: rramirez@ubo.cl with several compounds affect the replication process and hence this inhibits the growth of the tumor cells, this means antitumor effects.

This effect has been the basis for designing new and more efficient antitumor drugs. Moreover, their effectiveness depends on the mode and affinity of their binding ability to the DNA strands. ${ }^{13}$

The interactions between DNA and drugs has been considered as the main aspect that govern the DNA replications and transcription in cancer cells. ${ }^{14}$ It should be considered though, that not deep studies of DNA-Drug interactions and their toxicity have been performed..$^{15-17}$

This research focuses on the capacity of a chalcone's family (Figure 1) to interact with DNA. Therefore, the binding constants for the chalcone complexes with CT-DNA were determined by spectrophotometric titration at room temperature. These procedures were performed through the stepwise addition of a CT-DNA solution to a chalcone solution. In addition, the effect of the increasing chalcone's concentration over the relative viscosity of CT-DNA at room temperature was assessed..$^{18,19}$

\section{EXPERIMENTAL}

\section{Docking}

The docking procedure is envisaged as a complex optimization 


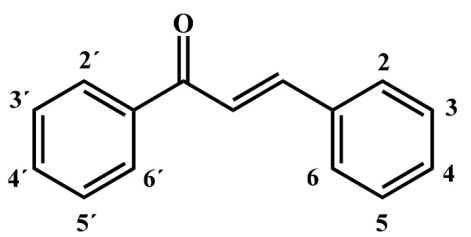

\begin{tabular}{|ccccccccc|}
\hline & $\mathbf{2}^{\prime}$ & $\mathbf{4}^{\prime}$ & $\mathbf{5}^{\prime}$ & $\mathbf{2}$ & $\mathbf{3}$ & $\mathbf{4}$ & $\mathbf{5}$ & $\mathbf{6}$ \\
\hline $\mathbf{C 1}$ & $\mathrm{OH}$ & $\mathrm{OCH}_{3}$ & $\mathrm{H}$ & $\mathrm{OCH}_{3}$ & $\mathrm{OCH}_{3}$ & $\mathrm{H}$ & $\mathrm{H}$ & $\mathrm{H}$ \\
$\mathbf{C 2}$ & $\mathrm{OH}$ & $\mathrm{H}$ & $\mathrm{H}$ & $\mathrm{OCH}_{3}$ & $\mathrm{H}$ & $\mathrm{OCH}_{3}$ & $\mathrm{H}$ & $\mathrm{H}$ \\
$\mathbf{C 3}$ & $\mathrm{H}$ & $\mathrm{H}$ & $\mathrm{Br}$ & $\mathrm{H}$ & $\mathrm{OCH}_{3}$ & $\mathrm{OCH}_{3}$ & $\mathrm{H}$ & $\mathrm{H}$ \\
$\mathbf{C} 4$ & $\mathrm{OH}$ & $\mathrm{OCH}_{3}$ & $\mathrm{H}$ & $\mathrm{OCH}_{3}$ & $\mathrm{H}$ & $\mathrm{H}$ & $\mathrm{OCH}_{3}$ & $\mathrm{H}$ \\
$\mathbf{C 5}$ & $\mathrm{H}$ & $\mathrm{OCH}_{3}$ & $\mathrm{H}$ & $\mathrm{H}$ & $\mathrm{H}$ & $\mathrm{Cl}$ & $\mathrm{H}$ & $\mathrm{Cl}$ \\
\hline
\end{tabular}

Figure 1. Chemical structures of the studied chalcones

or an exhaustive search process since it involves many degrees of freedom. The ultimate goal is to find the optimal ligand/DNA configurations, and to predict their binding free energy. To computationally accomplish this key objective within a reasonable time framework, an empirical scoring function (AScore) and a docking engine (ShapeDock) were employed in the ArgusLab program. ${ }^{20}$

The AScore is based on the deconvolution of the total DNA-ligand binding free energy into different components:

$\Delta \mathrm{G}_{\text {binding }}=\Delta \mathrm{G}_{\mathrm{vdW}}+\Delta \mathrm{G}_{\text {hydrophobic }}+\Delta \mathrm{G}_{\mathrm{H}-\text { bond }}+\Delta \mathrm{G}_{\mathrm{H}-\text { bond (chg) }}+$

$\Delta \mathrm{G}_{\text {deformation }}+\Delta \mathrm{G}^{\circ}$

The dissected terms account for the van der Waals interaction between the ligand and the DNA $\left(\Delta \mathrm{G}_{\mathrm{vdW}}\right)$, the hydrophobic effect ( $\Delta \mathrm{G}_{\text {hydrophobic }}$ ), the hydrogen bonding between the ligand and the protein $\left(\Delta \mathrm{G}_{\text {hydrophobic }}\right)$, the hydrogen bonding involving charged donor and/or acceptor groups $\left(\Delta \mathrm{G}_{\mathrm{H} \text {-bond(chg }}\right)$, the deformation effect $\left(\Delta \mathrm{G}_{\text {deformation }}\right)$, and the effects of the translational and rotational entropy loss in the bidding process $\left(\Delta \mathrm{G}^{\circ}\right)$.

The 3D structures of chalcones were first constructed using Arguslab , then were optimized using Austin Model 1 [AM1] , 200 maximum iteration, followed by conjugate gradient minimization to a RMS energy gradient of $0,01 \mathrm{kcal} / \mathrm{mol} .{ }^{21}$ Candidate conformations of Chalcones interacting to their target structures, the DNA complex, were proposed using Arguslab. ${ }^{22,23}$ Here, docking was carried out with a set of Chalcones. (Figure 1)

\section{Chemicals}

Synthesis of Chalcones, general methodology: Chalcones were prepared by adding dropwise a solution of the corresponding substituted benzaldehyde, $(7.34 \mathrm{mmol}$ in ethanol, $20 \mathrm{~mL})$ to a stirred mixture of 2-hydroxyacetophenone solution (7.34 mmol, in ethanol, $20 \mathrm{~mL}$ ) and potassium hydroxide solution $(2 \mathrm{~g}$ in $10 \mathrm{~mL}$ distilled water). The mixture was allowed to react overnight, and then, distilled water $(200 \mathrm{~mL})$ were added and neutralized with hydrochloric acid. Then, the mixture was extracted four times with ethyl acetate $(50 \mathrm{~mL})$. The combined organic fractions were concentrated in vacuum, dissolved in ethanol, and allowed to crystallize.

We have previously described the synthesis of the following compounds: 2,3,4'-trimethoxy-2'-hydroxy-chalcone $(\mathbf{1})^{1}$ which was obtained as orange crystals $(58 \%), \mathrm{mp} .129-130^{\circ} \mathrm{C}$; 2,4-dimethoxy-2'-hydroxy-chalcone $(2)^{1,7,24}$ obtained as yellow crystals (58\%), mp. $107-109.8^{\circ} \mathrm{C}$; 3'-bromo-3,4-dimethoxy-chalcone $(3)^{2.5}$ obtained as yellow crystals $(73 \%), \mathrm{mp} .117-120^{\circ} \mathrm{C}$; The following compounds were prepared as previously reported in the literature. Spectroscopic data were identical to those previously reported: 2,5,4'-trimethoxy-2'-hydroxy-chalcone (4) ${ }^{9}$ obtained as orange crystals (75\%) mp. $107-108^{\circ} \mathrm{C}$ and $4^{\prime}$-methoxy-2,4-dichloro-chalcone $(5)^{26}$ obtained as white crystals $(69 \%)$, mp. $136.1-137.4{ }^{\circ} \mathrm{C}$.

\section{Cell culture}

HUVEC-derived endothelial cell line, (EA.hy926) was kindly provided by C-J Edgell and was grown in Dulbecco's modified Eagle Medium (DMEM)-low glucose (GIBCO) supplemented with $10 \%$ heat-inactiva fetal bovine serum (FBS), $2 \mathrm{mmol} \mathrm{L}^{-1}$ and $50 \mathrm{U} \mathrm{mL}^{-1}$ penicilin/streptomycin (Sigma).

Human hepatocellular carcinoma HepG2 cells (American Type Culture Collection HB-8065) were grown in monolayer culture in DMEM-high glucose with $10 \%$ FBS and antibiotic-antimicotic (GIBCO). All cell cultures were grown at $37{ }^{\circ} \mathrm{C}$ in a $5 \%: 95 \% \mathrm{CO}_{2}$ : air atmosphere controlled.

\section{Cell viability assay}

Cell viability was evaluated using the 3-(4,5-dimethylthiazol-2-yl)-2,5-diphenyltetrazolium bromide (MTT) colorimetric assay (Invitrogen, Eugene, Oregon, USA). Cell viability was quantified by the amount of MTT reduction ${ }^{27}$ HepG2 and EA.hy926 were exposed to different concentrations of chalcones for 48 hours. After treatment cells were co-incubated with MTT $(0.5 \mathrm{mg} \mathrm{mL})$ for 4 hours, and then solubilized with an acidified $(0.04 \mathrm{~N} \mathrm{HCl})$ isopropanol/dimethyl sulfoxide (DMSO) solution. Optical density was measured at $540 \mathrm{~nm}$. All experiments were performed as triplicates. Data were expressed as percentage of survival cell. Cell survival (\%) data were plotted and adjusted to a sigmoidal best-fit curve, where: $\mathrm{IC}_{50}$ is the chalcone concentration to reach the half-maximal cell survival.

\section{Interaction of chalcones with CT-DNA by spectrophotometric titration}

Absorption spectroscopy is a useful tool to study the binding of drugs to DNA. Increments in DNA concentration result in shifts of absorption bands, which denote an effect of hyperchromism, resulting from a direct interaction between CT-DNA and the chalcones. These changes are similar to those small molecules that bind to double-stranded DNA through noncovalent interactions ${ }^{28,29}$

In this sense, the binding constants for the chalcone compounds with CT-DNA were determined by absorption titration at room temperature through the stepwise addition of a CT-DNA solution $\left(10 \mu \mathrm{L}, \sim 4 \times 10^{-4} \mathrm{~mol} \mathrm{~L}^{-1}\right)$ to a solution of each chalcone $(2 \mathrm{~mL}$ of (1) $4.8 \times 10^{-5} \mathrm{~mol} \mathrm{~L}^{-1}$, (2) $4.8 \times 10^{-5} \mathrm{~mol} \mathrm{~L}^{-1}$, (3) $5.6 \times 10^{-5} \mathrm{~mol} \mathrm{~L}^{-1}$, (4) $4.8 \times 10^{-5} \mathrm{~mol} \mathrm{~L}^{-1}$ and (5) $4.8 \times 10^{-5} \mathrm{~mol} \mathrm{~L}^{-1}$ ) in buffer Tris/ $\mathrm{HCl}$ and $\mathrm{NaOH}$ adjusted to $\mathrm{pH} 7.39$.

UV-vis absorption spectra were recorded between 190-1000 nm and the titration was finished when the intensity of those two bands did not change significantly upon further addition of CT-DNA. The binding constant $\mathrm{Kb}$ was calculated by using the Scatchard equation:

$$
\frac{[D N A]}{\left(\varepsilon_{a}-\varepsilon_{f}\right)}=\frac{[D N A]}{\left(\varepsilon_{b}-\varepsilon_{f}\right)}+\frac{1}{K_{b}\left(\varepsilon_{b}-\varepsilon_{f}\right)}
$$

where [DNA] is the concentration of DNA, $\varepsilon_{\mathrm{a}}$ is the molar absorption coefficient of the complex chalcone-DNA at given DNA concentration, $\varepsilon_{\mathrm{f}}$ is the molar absorption coefficient of the solution of the free chalcone and $\varepsilon_{\mathrm{b}}$ is the molar absorption coefficient of the chalcone when fully bound to DNA. A plot of [DNA $] /\left[\varepsilon_{\mathrm{a}}-\varepsilon_{\mathrm{f}}\right]$ vs [DNA] gives $1 /\left[\varepsilon_{b}-\varepsilon_{f}\right]$ as the angular coefficient. The $K_{b}$ is determined by a ratio between the angular and the linear coefficients. 


\section{Viscosity}

Hydrodynamic methods have been employed to test the binding mode of DNA to agents. In this sense, viscosity changes provide experimental advantages since viscosity is sensitive to length changes of DNA and the measures can reliably distinguish intercalation from groove binding. When intercalation is present, a planar ligand fragment is placed between adjacent base pairs, which induces lengthening of the helix. These interactions that result in the increase of the DNA length generate an increase of viscosity. On the other hand, a groove binder, typically carries out subtle changes and the DNA remains in the unperturbed form and not increase of the DNA length is observed, therefore this binding mode shows no increase of the viscosity of the DNA solutions. ${ }^{18,19}$

In the herein work, the effect of the increasing concentration of chalcones over the relative viscosity of CT-DNA at room temperature was measured employing a viscosimeter Anton Par Lovis 2000M. The values for relative specific viscosity $\left(\eta / \eta_{0}\right)^{1 / 3}$, where $\eta_{0}$ is the specific viscosity contributions of DNA in absence of compound and $\eta$ is the viscosity in the presence of the complex, were plotted against [complex]/[DNA] where [complex] is the concentration of the chalcones and [DNA] is the concentration of CT-DNA.

\section{RESULTS AND DISCUSSION}

The fact of inhibiting the replication process of DNA by action of drugs is the motivation of designing new and more efficient antitumor drugs. Moreover, their effectiveness depends on the mode and affinity of their binding ability to the DNA strands. ${ }^{13}$ It is for this reason that we employed two cell lines, which have different DNA replication rate, where HepG2 cells have a high rate of replication with respect to EA.hy 296 cells. The interactions of chalcones with DNA may have
Table 1. Relationship between $\mathrm{IC}_{50}[\mu \mathrm{M}]$; HepG2 , EAhy926, Kb and $\Delta \mathrm{G}$ $[\mathrm{kcal} / \mathrm{mol}]$

\begin{tabular}{|c|c|c|c|c|}
\hline \multirow[b]{2}{*}{ Chalcone } & EAhy.926 & HepG2 & \multirow{2}{*}{$\begin{array}{c}\mathrm{dG} \\
{\left[\mathrm{kcal} \mathrm{mol}^{-1}\right]}\end{array}$} & \multirow[b]{2}{*}{$\mathrm{Kb}$} \\
\hline & $\begin{array}{c}\text { IC50 } \\
{\left[\mu \mathrm{mol} \mathrm{L}{ }^{-1}\right]}\end{array}$ & $\begin{array}{c}\text { IC50 } \\
{\left[\mu \mathrm{mol} \mathrm{L}{ }^{-1}\right]}\end{array}$ & & \\
\hline 1 & 7.66 & 10.64 & -4.06 & $2.33 \mathrm{E}^{+03}$ \\
\hline 2 & 10.73 & 31.26 & -4.06 & $2.33 \mathrm{E}^{+04}$ \\
\hline 3 & 3.91 & 8.27 & -4.04 & $3.33 \mathrm{E}^{+04}$ \\
\hline 4 & 12.52 & 21.40 & -3.98 & $3.75 \mathrm{E}^{+03}$ \\
\hline 5 & 11.92 & 26.18 & -4.13 & $2.58 \mathrm{E}^{+04}$ \\
\hline
\end{tabular}

a crucial relevance in its induction of tumor cell death. Our results showed a higher cytotoxic effect of chalcones in EA.hy296 cells compared to HepG2 cells (Table 1).

This selectivity of chalcones could be explained by a lower rate of DNA replication observed in EA.hy296 cells, however both lines are tumor and have low $\mathrm{IC}_{50}$, experiments in primary cultures of normal cells are necessary to determine their selectivity only to tumor cells. The $\mathrm{IC}_{50}$ and $\mathrm{Kd}$ values for the chalcone's family studied here were compared in both cell lines. To compare the effect of chalcones on HepG2 and EA.hy296 cells, a correlation between IC50 and Kd was established (Table 1). The docking computations suggest that the chalcones does interact with DNA via intercalation and that the chalcones exhibits affinity for double stranded DNA as shown in Figure 2, such interaction with the nucleic acids could inhibit cellular DNA synthesis during DNA replication.

According to this docking experiment, the complexes reasonably bind with DNA. The minimum energy obtained for a docked structure (Figure 2) suggest that the best possible conformation of the ligand
C1
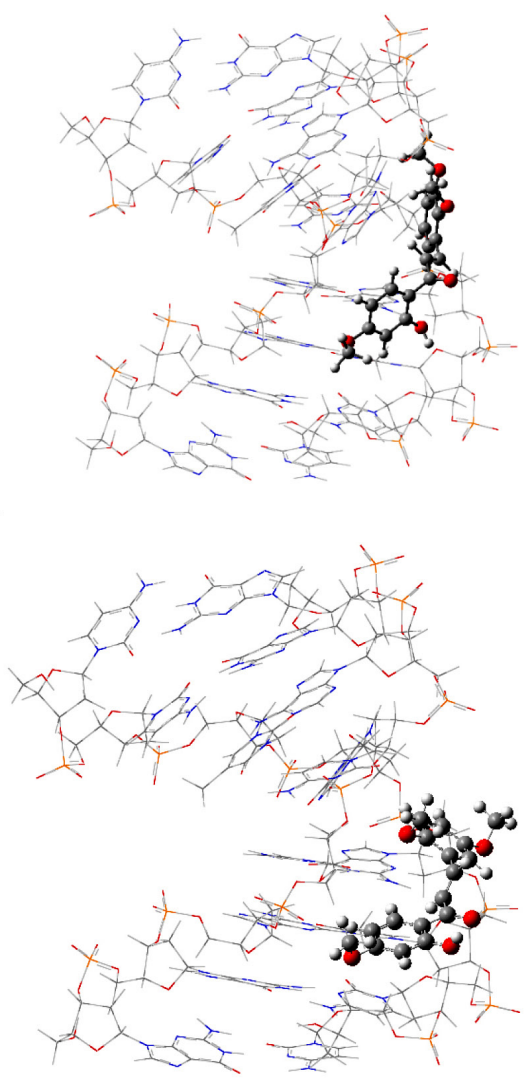

C2

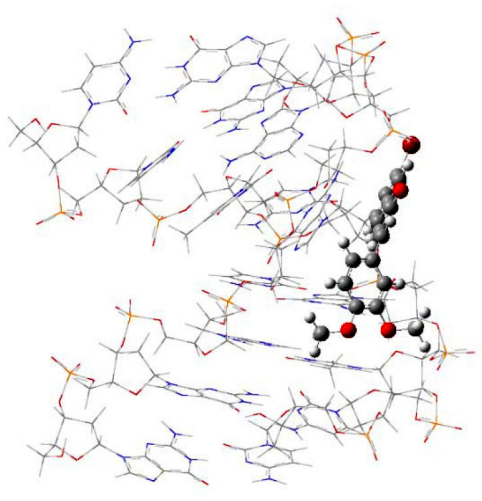

C3

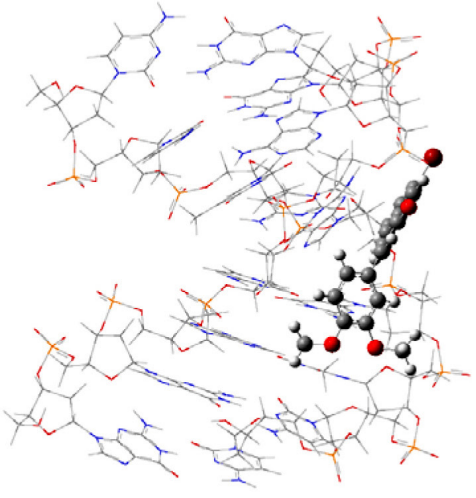

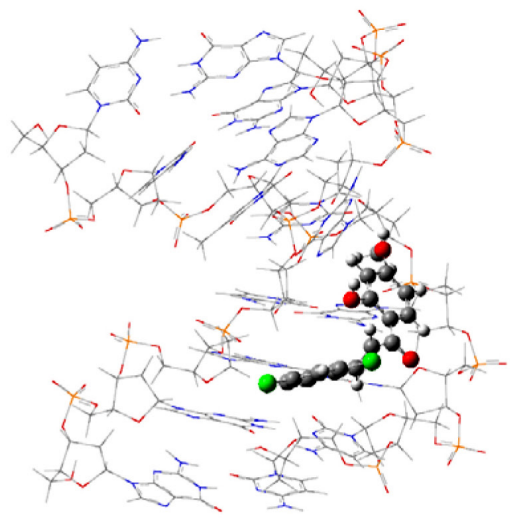

Figure 2. Molecular simulations of chalcones with DNA 
interaction, is mainly through the aromatic ring being inside the DNA strand. It has been observed that the complex is stabilized by electrostatic hydrogen bonding with DNA bases, in addition to van der Waal's and stacking-bond interactions between electron deficient chalcone ring and purine-pyrimidine bases. The binding energy values are presented in Table 1 .

Chalcones can bind with double-stranded DNA in various binding modes on the basis of its structure. However, hypochromic effect could be attributed to the stacking interaction between the aromatic rings of the ligand framework and DNA base pairs as well. The hypochromism and bathochromic shifts may commonly vary in consistence with the strength of intercalative interaction of the complex with DNA helix as well as overall conformation of the DNA. The
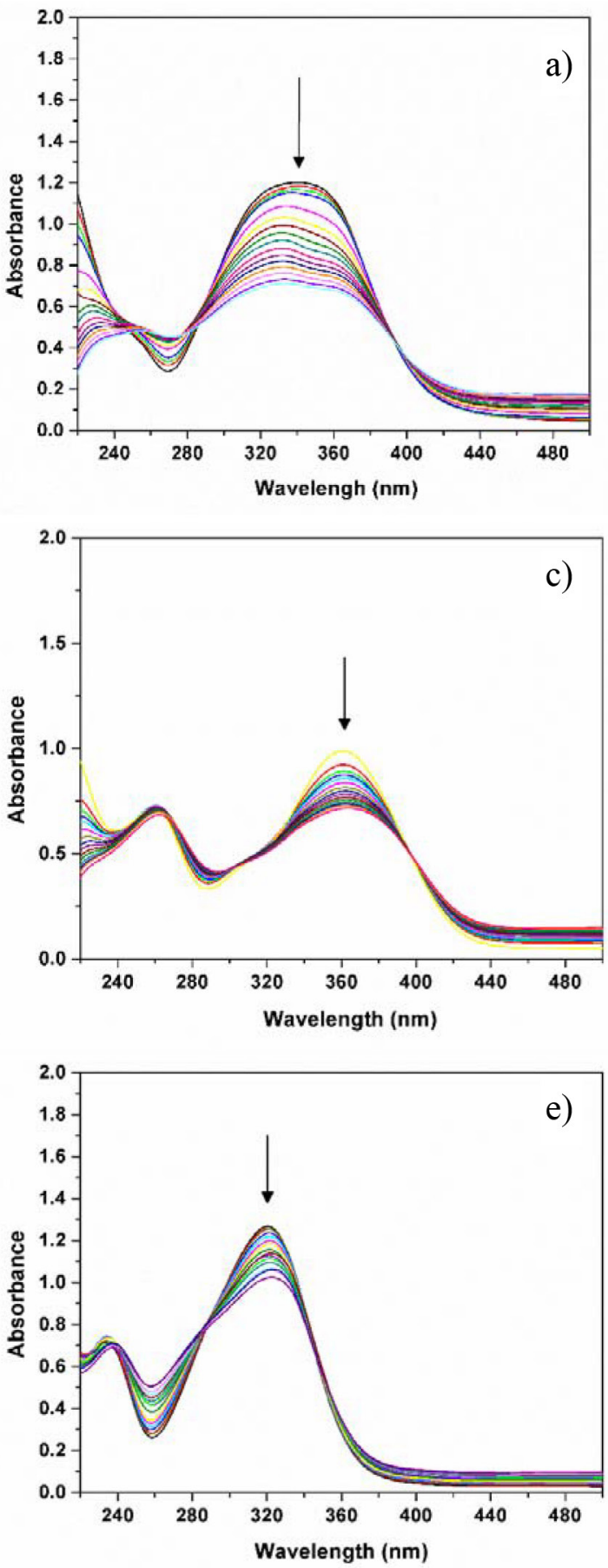

intrinsic binding constant of the chalcones with DNA was measured as $\mathrm{Kb}$ (see Methods). The low value of the binding constant obtained here $\left(\mathrm{Kb}=\mathbf{C 1} 2.33 \times 10^{3}, \mathbf{C 2} 2.33 \times 10^{4}, \mathbf{C 3} 3.33 \times 10^{4}, \mathbf{C 4} 3.75 \times 10^{3}\right.$, C5 $\left.2.58 \times 10^{4}\right)$ suggests that the chalcones interacts with DNA double strand in an intercalated manner (Figure 3 ).

On the other hand, taking into account the viscosity measurements, on increasing the amounts of $\mathrm{C} 4>\mathrm{C} 5>\mathrm{C} 1>\mathrm{C} 2>\mathrm{C} 3$ bound to DNA, the relative viscosity of the DNA increases steadily (Figure 4). The observed linear increase in viscosity as a function of chalcone content for all compounds across the range of the relation of chalcone-DNA concentrations, suggests the fact that the interaction of the compounds with the DNA leads to increase the length of the DNA chains, which is indicative of the classical intercalation model. ${ }^{18,19}$
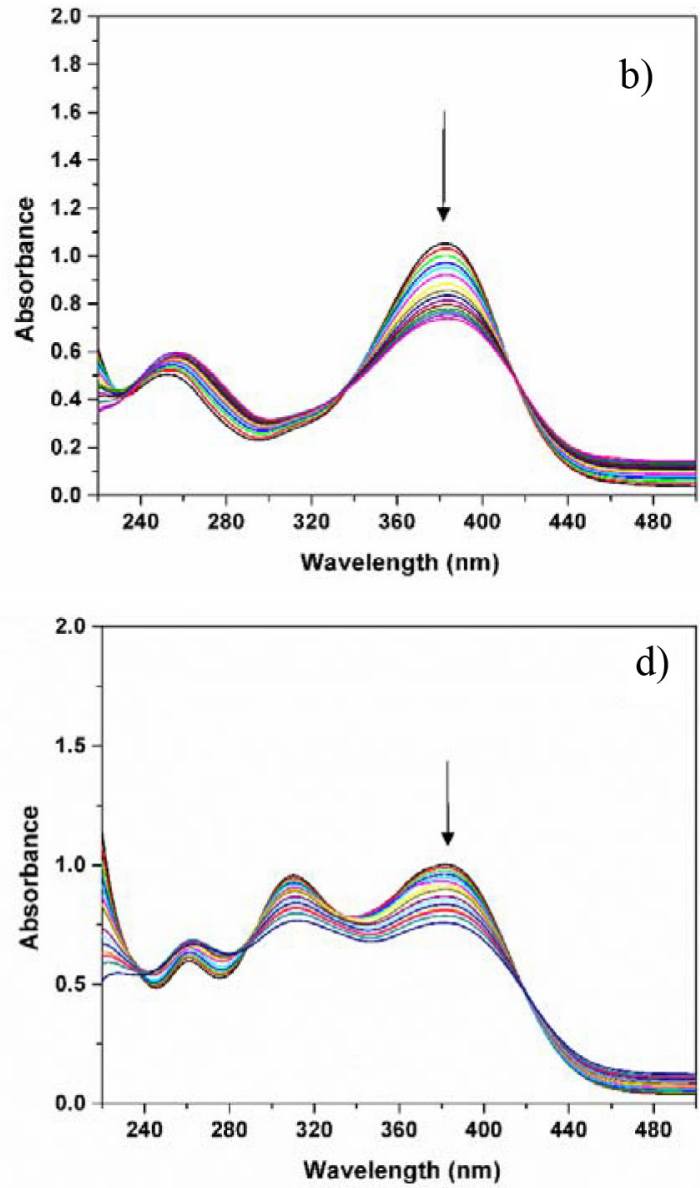
Finally, the results of UV-vis spectroscopy, viscosity and docking measurement showed that chalcones binds with DNA via intercalation. It also suggests that the interactions of the chalcones caused a change in the conformation of DNA and thus an increase in intensity of the antitumoral activity was generally observed. Moreover, the results described in this study showed that changing the ligand environment could modulate the binding property of the chalcones with DNA.

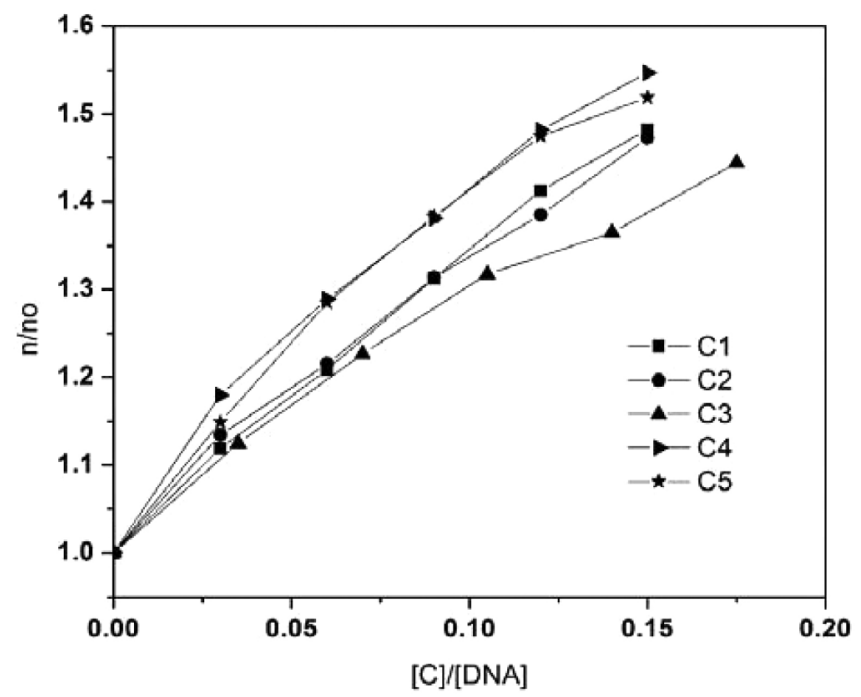

Figure 4. Viscometry of calf thymus-DNA modified by chalcones

\section{CONCLUSIONS}

Three different approaches (spectrophotometric analysis, viscosity and molecular modeling) were considered to study the interaction between a family of chalcones and DNA.

After satisfactory spectroscopic measurements of the DNA binding ability with the studied compounds, molecular docking calculations were performed to understand the preferred orientation of sterically acceptable complexes.

Furthermore, increase in viscosity measured in the viscosity studies of chalcones-DNA complexes, helped to corroborate that the chalcones and DNA can interact via intercalation.

In general, the experimental and theoretical calculations indicated the presence of interactions between the chalcone's family with CTDNA, which could explain the differences in cytotoxicity obtained in different cell types, since DNA replication is frequent in highly proliferating cells.

\section{ACKNOWLEDGEMENTS}

Fondecyt 11130007 and 3140002

\section{REFERENCES}

1 Alarcón, J.; Alderete, J.; Escobar, C.; Araya, R.; Cespedes, C. L.; Biocatal. Biotransform. 2013, 31, 160.

2 Rahman, M. A.; Chem. Sci. 2011, 2011, 1.
3 Tadigoppula, N.; Korthikunta, V.; Gupta, S.; Kancharla, P.; Khaliq, T.; Soni, A.; Srivastava, R. K.; Srivastava, K.; Puri, S. K.; Raju, K. S. R.; Sijwali, P. S.; Kumar, V.; Mohammad, I. S.; J. Med. Chem. 2013, 56, 31.

4 Shenvi, S.; Kumar, K.; Hatti, K. S.; Rijesh, K.; Diwakar, L.; Reddy, G. C.; Eur. J. Med. Chem. 2013, 62, 435.

5 Singh, P.; Anand, A.; Kumar, V.; Eur. J. Med. Chem. 2014, 85C, 758.

6 Dickson, J.; Flores, L.; Stewart, M.; LeBlanc, R.; Pati, H. N.; Lee, M.; Holt, H.; J. Chem. Educ. 2006, 83, 934.

7 Echeverria, C.; Santibañez, J. F.; Donoso-Tauda, O.; Escobar, C. A.; Ramirez-Tagle, R.; Int. J. Mol. Sci. 2009, 10, 221.

8 Detsi, A.; Majdalani, M.; Kontogiorgis, C. A.; Hadjipavlou-Litina, D.; Kefalas, P.; Bioorg. Med. Chem. 2009, 17, 8073.

9 Boumendjel, A.; Boccard, J.; Carrupt, P.-A.; Nicolle, E.; Blanc, M.; Geze, A.; Choisnard, L.; Wouessidjewe, D.; Matera, E.-L.; Dumontet, C.; J. Med. Chem. 2008, 51, 2307.

10 Wan, Z.; Hu, D.; Li, P.; Xie, D.; Gan, X.; Molecules 2015, 20, 11861.

11 Chiavarino, B.; Crestoni, M. E.; Fornarini, S.; Scuderi, D.; Salpin, J.-Y.; J. Am. Chem. Soc. 2013, 135, 1445.

12 Nagababu, P.; Shilpa, M.; Latha, J. N. L.; Bhatnagar, I.; Srinivas, P. N. B. S.; Kumar, Y. P.; Reddy, K. L.; Satyanarayana, S.; J. Fluoresc. 2011, $21,563$.

13 Dixit, R. B.; Patel, T. S.; Vanparia, S. F.; Kunjadiya, A. P.; Keharia, H. R.; Dixit, B. C.; Sci. Pharm. 2011, 79, 293.

14 Kennard, O.; Pure Appl. Chem. 1993.

15 Hühn, D.; Bolck, H. A.; Sartori, A. A.; Swiss Med. Wkly. 2013, 143, w13837.

16 Bhat, S. S.; Kumbhar, A. A.; Heptullah, H.; Khan, A. A.; Gobre, V. V.; Gejji, S. P.; Puranik, V. G.; Inorg. Chem. 2011, 50, 545.

17 Shaheen, F. S.; Znojek, P.; Fisher, A.; Webster, M.; Plummer, R.; Gaughan, L.; Smith, G. C. M.; Leung, H. Y.; Curtin, N. J.; Robson, C. N.; PLoS One 2011, 6.

18 Suh, D.; Chaires, J. B.; Bioorg. Med. Chem. 1995, 3, 723.

19 Plsikova, J.; Janovec, L.; Koval, J.; Ungvarsky, J.; Mikes, J.; Jendzelovsky, R.; Fedorocko, P.; Imrich, J.; Kristian, P.; Kasparkova, J.; Brabec, V.; Kozurkova, M.; Eur. J. Med. Chem. 2012, 57, 283.

20 Oda, A.; Takahashi, O.; Chem-Bio Inf. J. 2009, 9, 52.

21 Dewar, M. J. S.; Zoebisch, E. G.; Healy, E. F.; Stewart, J. J. P.; J. Am. Chem. Soc. 1985, 107, 3902.

22 Mihajlovic, M.; Mitrasinovic, P.; J. Serbian Chem. Soc. 2009, 74, 1.

23 Rajamanikandan, S.; Sindhu, T.; Durgapriya, D.; Anitha, J. R. A. J.; Akila, S.; Gopalakrishnan, V. K.; Int. J. Pharm. Pharm. Sci. 2011, 3, 168.

24 Quintana-Espinoza, P.; Yáñez, C.; Escobar, C. A.; Sicker, D.; ArayaMaturana, R.; Squella, J. A.; Electroanalysis 2006, 18, 521.

25 Escobar, C. A.; Trujillo, A.; Howard, J. A. K.; Fuentealba, M.; Acta Crystallogr., Sect. E: Struct. Rep. Online 2012, 68, o887.

26 Perjéssy, A.; Al-Amood, H. K.; Fadhil, G. F.; Prónayová, N.; J. Phys. Org. Chem. 2011, 24, 140.

27 Mosmann, T.; J. Immunol. Methods 1983, 65, 55.

28 Hirohama, T.; Kuranuki, Y.; Ebina, E.; Sugizaki, T.; Arii, H.; Chikira, M.; Selvi, P. T.; Palaniandavar, M.; J. Inorg. Biochem. 2005, 99, 1205.

29 Marković, V.; Debeljak, N.; Stanojković, T.; Kolundžija, B.; Sladić, D.; Vujčić, M.; Janović, B.; Tanić, N.; Perović, M.; Tešić, V.; Antić, J.; Joksović, M. D.; Eur. J. Med. Chem. 2015, 89, 401. 